\title{
Combined effects of tricaprylin, coconut oil and amount of lipid, carbohydrate and protein on the digestibility of a milk replacer offered to the preruminant lamb and on energy and nitrogen balance
}

\author{
B. Aurousseau ${ }^{1}, M$. Vermorel ${ }^{1}$ and $M$. Theriez 2 \\ with the technical assistance of F. Duboisset, J.P. Donnat, S. Gasnet, M. Martinaud, \\ G. Moins and R. Souchet
}

\author{
' INRA, laboratoire d'étude du métabolisme énergétique, CRVZ Theix, 63122 Ceyrat; \\ 2 INRA, laboratoire de la production ovine, centre de recherches de Clermont-Ferrand, CRVZ Theix, \\ 63122 Ceyrat, France
}

(received 25 October 1988; accepted 21 May 1989)

\begin{abstract}
Summary - The effects, according to the age of the animals, of tricaprylin in addition to coconut oil on the digestibility of the constituents of the milk substitutes, on energy and nitrogen balances, and on growth and feed efficiency before weaning were studied in a trial comprising two parts. Two different diets (C, Ta), containing 160 or $95 \mathrm{~g}$ tallow, 90 or $53 \mathrm{~g}$ coconut oil, 0 or $50 \mathrm{~g}$ tricaprylin, 250 or $269 \mathrm{~g}$ protein, 22.2 or $20.8 \mathrm{MJ}$ gross energy per $\mathrm{kg}$ dry matter, were prepared. The different protein and energy contents of the 2 diets were due to the flotation of part of the lipids in the case of diet Ta.

Part 1 involved 50 male Limousin or Romanov $\times$ Limousin preruminant lambs, used in two replicates, each comprising 2 series of energy (obtained by indirect calorimetry) and nitrogen balance at 2 or 5 weeks (first replicate, series 1 and 2), or at 2, 4 or 6 weeks (second replicate, series 3 and 4). Part 2 was a feeding trial involving 51 Limousin and Romanov $\times$ Limousin preruminant lambs, used in two replicates. Growth rates and feed efficiency were obtained between 10 and 35 days.

The nitrogen digestibility was higher in 5-week-old lambs who were fed diet $\mathrm{Ta}$, or for all the lambs fed diet Ta taken together $(P<0.05)$. Respective digestibilities of energy and nitrogen increased from 95.5 to $98.3 \%$ and from 97.0 to $98.3 \%$ between the second and the sixth week of age $(P<0.025)$. A higher protein efficiency $(P<0.05)$, and a higher level of nitrogen balance $(P<0.005)$ of the same magnitude at all ages $(+14$ to $+25 \%)$ were obtained in lambs who were fed diet Ta. Efficiency of ME utilization for energy $\left(k_{f}=0.72\right)$, protein $\left(k_{p}=0.62\right)$, or lipid $\left(k_{1}=0.87\right)$ deposition and maintenance requirements (MEm $=411$ to $451 \mathrm{KJ} \mathrm{kg}^{-1}\left(\mathrm{~W}{ }^{0.75} \mathrm{~d}\right.$ ) were not altered by the type of diet. Those results were discussed in relation to the respective effects of tricaprylin, carbohydrates and protein contents of the diet.
\end{abstract}

preruminant lamb - tricaprylin — energy and nitrogen balance

Résumé - Effets combinés de la tricapryline, de l'huile de coprah et de la quantité de lipides, de glucides et de protéines sur la digestibilité d'un lait de remplacement offert à l'agneau préruminant et sur les bilans d'azote et d'énergie. Les variations en fonction de l'âge des animaux, des effets de l'addition de tricapryline à des laits de remplacement déjà enrichis en huile de coprah, sur la digestibilité des constituants de la ration, les bilans d'énergie et d'azote, la vitesse de croissance et l'efficacité d'utilisation des aliments pour la croissance, ont été étudiés chez l'agneau préruminant, au cours d'une expérience composée de deux parties. Deux aliments (C, Ta) comportant 160 ou $95 \mathrm{~g}$ de suif, 90 ou $53 \mathrm{~g}$ d'huile de coprah, 0 ou $50 \mathrm{~g}$ de tricapryline, 250 ou $269 \mathrm{~g}$ de pro- 
téines et 22,2 ou 20,8 MJ énergie brute par $\mathrm{kg}$ de matière sèche ont été utilisés. Les différences de teneurs en protéines et en énergie entre les deux aliments ont été dues au fait qu'une partie des lipides du lait Ta a surnagé.

La première partie de l'expérience a mis en jeu 50 agneaux mâles préruminants Limousins ou Romanov $x$ Limousins, au cours de deux répétitions comprenant chacune deux séries de mesures de bilans d'énergie (par calorimétrie indirecte) et d'azote, à 2 ou à 5 semaines (première répétition, séries 1 et 2), ou à 2, 4 ou 6 semaines (deuxième répétition, séries 3 et 4). La deuxième partie était une expérience d'alimentation en lots, sur 51 agneaux préruminants Limousins ou Romanov $x$ Limousins, au cours de deux répétitions. Les vitesses de croissance et l'efficacité d'utilisation des aliments pour la croissance ont été étudiées entre 10 et 35 jours.

La digestibilité de l'azote a été plus élevée chez les agneaux de 5 semaines recevant l'aliment Ta, ou pour l'ensemble des résultats obtenus avec cet aliment $(\mathrm{P}<0,05)$. Les digestibilités respectives de l'énergie et de l'azote ont augmenté de 95,5 à $98,3 \%$ ou de 97,0 à $98,3 \%$ entre la deuxième et la sixième semaine $(\mathrm{P}<0,025)$. Une efficacité plus grande de l'utilisation des protéines alimentaires pour la croissance $(\mathbf{P}<0,05)$ et un niveau plus élevé de fixation d'azote dans les tissus $(\mathbf{P}<0,005)$, similaire à tous les âges $(+14$ à $+25 \%)$ ont été observés chez les agneaux qui ont reçu l'aliment Ta. L'efficacité d'utilisation de l'énergie métabolisable pour la fixation dans les tissus d'énergie $\left(k_{f}=0,72\right)$, de protéines $\left(k_{p}=0,62\right)$, ou de lipides $\left(k_{l}=0,87\right)$, ainsi que les besoins d'entretien (EMe: 411 à $451 \mathrm{KJ} \mathrm{kg}$ $\left(P^{0.75} j^{-1}\right)$ ont été identiques pour les deux types d'aliments.

Les différences entre les régimes pourraient être dues à la tricapryline ou à la plus grande teneur en glucides et en protéines de l'aliment Ta. Selon les résultats antérieurs, aucun des 3 facteurs ne peut rendre compte à lui-seul, de l'amplitude inhabituelle des effets observés qui paraît liée à l'interaction entre la présence de tricapryline et la plus grande teneur en glucides de l'aliment expérimental. Ces résultats apparaissent intéressants pour la formulation d'aliments mieux adaptés aux potentialités de croissance des jeunes préruminants, et en particulier à la nutrition de l'agneau présentant un faible poids de naissance, suite à une sous-alimentation in utero.

agneau préruminant - tricapryline - fixation d'énergie et d'azote

\section{INTRODUCTION}

In previous studies in the preruminant animal (Aurousseau et al., 1989, in the lamb; Aurousseau, Thivend \& Vermorel, 1984; Aurousseau, Vermorel \& Bouvier, 1984, in the calf), trycaprilin has been shown to be a guarantee of efficient digestibility of the milk constituents and to allow for a higher level of intake and higher feed efficiency. Tricaprylin, therefore, could be a suitable energy source for the nutrition of the small for date lamb born from multiple-fœtus bearing ewes. However, the effect of tricaprylin appeared to be higher in the youngest animals (Aurousseau, Thivend \& Vermorel, 1984, in the calf; Aurousseau et al., 1989, in the lamb).
Coconut oil, a natural source of medium chain fatty acid (MCFA, $45 \%$ of lauric acid and $17 \%$ of myristic acid) was also shown to be efficiently digested and to allow for high levels of intake, increased nitrogen balances and higher growth rates in preruminant animals (Walker \& Stokes, 1970; Theriez et al., 1973; Aurousseau et al., 1989 , in the lamb; Aurousseau, Vermorel \& Bouvier, 1984, in the calf). Coconut oil incorporated into a milk substitute given before weaning was also beneficial for the composition of adipose tissue at slaughter, about 100 days later (Aurousseau et al., 1973). However, coconut oil also lead to high amounts of adipose tissue being laid down (Theriez et al., 1973), whereas, tricaprylin was shown to decrease the amount of adipose tissue in the body of the 
rat (Baba et al., 1982), in the infant (Huston et al., 1983) or in the piglet (Newport et al., 1979).

We therefore investigated more thoroughly the variations of the effect of tricaprylin with the age of the lambs, as well as, the possible interaction of tricaprylin and coconut oil on the digestion, nitrogen balance and energy utilization, growth-rate and feed efficiency of the preruminant lamb. The effects on carcass composition at weaning, as well as, long term effects on postweaning growth and carcass characteristics were also investigated and will be reported in a forthcoming paper.

\section{MATERIALS AND METHODS}

\section{Milk replacers}

Two milk-substitutes (C, T), with a protein content of $250 \mathrm{mg} / \mathrm{g}$ dry matter (DM) were prepared (Table I). Diet $\mathrm{C}$ had a lipid content of $250 \mathrm{mg} \mathrm{g}^{-1}$ (DM), composed of tallow ( $64 \%$ of total fat) and coconut oil ( $36 \%$ of total fat), and an energy content of 22.2 $\mathrm{KJ}^{-1}$ (DM). The milk substitute was reconstituted at a rate of $165 \mathrm{~g}$ spray-dried powder for $1 \mathrm{~kg}$ liquid diet.

Table 1. Composition of the milk-substitutes.

\begin{tabular}{|c|c|c|c|}
\hline Diet & $C$ & \multicolumn{2}{|c|}{$T$} \\
\hline \multicolumn{4}{|c|}{ Diet constituents $(g / k g-1(D M))$} \\
\hline $\begin{array}{l}\text { Skim-milk powder } \\
\text { Tallow } \\
\text { Coconut oil } \\
\text { Tricaprylin } \\
\text { Soja lecthin } \\
\text { Supplements (1) }\end{array}$ & $\begin{array}{r}716 \\
160 \\
90 \\
14 \\
20\end{array}$ & & \\
\hline Diet & $C$ & $T$ & $\operatorname{Ta}(2)$ \\
\hline \multicolumn{4}{|l|}{ Chemical constituents } \\
\hline $\begin{array}{l}\text { Dry matter }(\mathrm{g} / \mathrm{kg}) \\
\text { Lipid (mg/g (DM)) } \\
\text { Protein (mg/g (DM)) } \\
\text { Gross energy (KJ/g (DM)) }\end{array}$ & $\begin{array}{r}165 \\
250 \\
252 \\
22.2\end{array}$ & $\begin{array}{r}165 \\
260 \\
251 \\
22.2\end{array}$ & $\begin{array}{l}149 \\
198 \\
269 \\
20.8\end{array}$ \\
\hline
\end{tabular}

(1) $4 \mathrm{Mg} \mathrm{Cl}_{2} 6 \mathrm{H}_{2} \mathrm{O} ; 50 \mathrm{mg} \mathrm{Fe} \mathrm{SO} 47 \mathrm{H}_{2} \mathrm{O} ; 50 \mathrm{mg} \mathrm{Mn} \mathrm{SO} 44 \mathrm{H}_{2} 0 ; 20 \mathrm{mg} \mathrm{Cu} \mathrm{SO}, 5 \mathrm{H}_{2} \mathrm{O} ; 8 \mathrm{mg} \mathrm{Kl} ; 0.6 \mathrm{mg} \mathrm{Co} \mathrm{Cl} ; 3.6$ $\mathrm{mg}$ vitamin $\mathrm{D} ; 50 \mathrm{mg}$ vitamin $\mathrm{E} ; 2 \mathrm{mg}$ vitamin $\mathrm{K} ; 2 \mathrm{mg}$ vitamin $\mathrm{B}_{1} ; 4 \mathrm{mg}$ vitamin $\mathrm{B}_{2} ; 2 \mathrm{mg}$ vitamin $\mathrm{B}_{6} ; 0.05 \mathrm{mg}$ vitamin $\mathrm{B}_{12} ; 0.75 \mathrm{mg}$ biotin; $2 \mathrm{mg}$ calcium pantothenate; $1.8 \mathrm{~g}$ choline; $50 \mathrm{mg}$ furazolidone.

(2) Part of lipid of diet 8 floated, so that the ingested diet had a higher protein content and a lower energy content than planned. 
Diet $T$ was prepared as follows : a spray-dried tricaprylin-free powder was prepared (protein, lipid and energy contents were respectively $277,182 \mathrm{mg} \mathrm{g}^{-1}$ (DM) and $21 \mathrm{KJ} \mathrm{g}^{-1}(\mathrm{DM})$ ); milk substitute was then reconstituted at a rate of $149 \mathrm{~g}$ powder and $17 \mathrm{~g}$ tricaprylin for $1 \mathrm{~kg}$ liquid diet.

In the case of diet T, part of the lipid floated so that the ingested milk replacer (Ta) had a protein content of $269 \mathrm{mg} / \mathrm{g}$ DM, a lipid content of $198 \mathrm{mg} / \mathrm{g}$ DM (made up of $48 \%, 27 \%$ and $25 \%$ of total fat, respectively, as tallow, coconut oil and tricaprylin), and an energy content of 20.8 $\mathrm{KJ} \mathrm{kg}^{-1}$ (DM). However, when there were no milk refusals, the ingested milk had a composition similar to diet C (Table I), with a lipid content $\left(260 \mathrm{mg} \mathrm{g}^{-1}\right.$ (DM), made up of $41 \%$ tallow, $23 \%$ coconut oil and $36 \%$ tricaprylin), which is slightly higher than diet $\mathrm{C}$, taking into account the lower energy content of tricaprylin $\left(33.4 \mathrm{KJ} \mathrm{g}^{-1}\right)$, than that of the mixture of tallow and coconut oil (about $38.4 \mathrm{KJ} \mathrm{g}^{-1}$ ).

\section{Animals and their management (Table II)}

The complete trial was organized in two parts, each comprising two replicates carried out at one-year intervals :

Table II. Synopsis of the whole trial.

\begin{tabular}{|c|c|c|c|c|c|c|c|c|c|}
\hline & & & & & & & leeks & & \\
\hline & Replicate & Series & Diet & 2 & & 4 & 5 & 6 & Observations \\
\hline & & & & (1) & & (1) & (1) & (1) & \\
\hline & $1 s t$ & 1 & C & 6 & & - & 4 & - & Digestibility \\
\hline Part 1 & & & $\mathrm{Ta}$ & 6 & & - & 4 & - & $\begin{array}{l}\text { Individual nitrogen } \\
\text { balances, }\end{array}$ \\
\hline & & & C & 7 & & - & 4 & - & Energy balances in \\
\hline & & 2 & $\mathrm{Ta}$ & 7 & & - & 4 & - & $\begin{array}{l}\text { groups (respiratory } \\
\text { chambers) }\end{array}$ \\
\hline & 2nd & 3 & $\mathrm{C}$ & 5 & & 4 & - & 4 & \\
\hline & & 4 & $\begin{array}{c}\mathrm{C} \\
\mathrm{Ta}\end{array}$ & $\begin{array}{l}7 \\
7\end{array}$ & & $\begin{array}{l}4 \\
4\end{array}$ & - & $\begin{array}{l}4 \\
4\end{array}$ & \\
\hline & & & & & (2) & & (1) & (3) & \\
\hline & 1st & - & C & 10 & to & 35 & 11 & (4) & Level of intake and \\
\hline Part 2 & & & $\underset{\mathrm{T}}{\mathrm{Ta}}$ & & & & $\begin{array}{r}12 \\
6\end{array}$ & $\begin{array}{l}(4) \\
(2)\end{array}$ & feed efficiency \\
\hline & 2nd & - & $\begin{array}{r}\mathrm{C} \\
\mathrm{Ta}\end{array}$ & 10 & to & 45 & $\begin{array}{l}11 \\
11\end{array}$ & $\begin{array}{l}(*) \\
(*)\end{array}$ & \\
\hline
\end{tabular}

(1) Number of lambs.

(2) Age of the lambs (days) .

(3) Between brackets : Number of groups; " : lambs held in inddividual pens. 
- part 1 comprised 21 male preruminant Limousin lambs and 29 male preruminant Romanov $\times$ Limousin lambs, on which digestibility, energy and nitrogen balance, feed efficiency and carcass composition were studied,

- part 2 was a feeding trial, comprising 28 male preruminant Limousin lambs, 17 male preruminant Romanov $\times$ Limousin lambs and 6 female preruminant Romanov $x$ Limousin lambs, on which growth rates and feed efficiency were examined.

Each replicate of part 1 (Table II), included two series of digestibility and energy and nitrogen balance determinations on pairs of homologous groups of lambs who were fed diets $\mathrm{C}$ and $\mathrm{T}$ (Ta). The different groups involved were $6,7,5$, or 7 2-weekold lambs, respectively for series $1,2,3,4$, or homologous groups of 4 five-week-old lambs (series 1 and 2) or 4- or 6-week-old lambs (series 3 and 4).

The first replicate of part 2 comprised 14 male preruminant Limousin lambs, 9 male preruminant Romanov $\times$ Limousin lambs and 6 female preruminant Romanov $x$ Limousin lambs separated into groups of 2 or 3 lambs each installed in large pens on an earth floor. The lambs were fed either diet $\mathrm{C}$ ad libitum (11 lambs separated into 4 groups), diet $\mathrm{T}$ (Ta) ad libitum (12 lambs separated into 4 groups), or diet $T$ offered in amounts restricted to $80 \%$ of ad libitum level of intake ( 6 lambs separated into 2 groups).

The second replicate of part 2 comprised 14 male preruminant Limousin lambs and 8 male preruminant Romanov $x$ Limousin lambs individually fed diet $C$ (11 lambs) or diet $\mathrm{T}$ (Ta, 11 lambs), ad libitum.

All the lambs were weaned from the ewe after being allowed to suckle their mother for 24 hours. In part 1 of the trial, the lambs were fitted with equipment for faeces collection (described by Brisson et al., 1970), and each group was installed in metabolic crates disposed inside identical parallel epipedic frames, in which 6 individuals crates for 2-week-old lambs or 4 individual crates for older lambs could be arranged. Urine was collected in flasks (containing $100 \mathrm{ml} 6 \mathrm{M}$-hydrochloric acid to prevent any ammonia loss) with the help of rigid plastic funnels held under the wirefloor of the crates. The frames, in which the different groups of animals were held in their individual crates, were installed in respiratory chambers. After 2 days of adaptation, $\mathrm{O}_{2}$ consumption and $\mathrm{CO}_{2}$ production were measured for 3 to 4 consecutive days on all the groups of lambs, and used to determine energy balance (as described by Vermorel et al., 1973).

A liquid diet was offered in plastic flasks equipped with nipples fitted with plastic tubing plunging to the bottom of the flasks. Liquid milk was offered twice daily and the amounts offered and refused were controlled; representative samples were gathered for analysis. The lambs were weighed at birth, at the beginning and at the end of the balance determination periods, or every week. They were weaned at 35 days of age in the case of first replicates of both parts of the trial, or at 45 days of age in the case of second replicates.

At weaning, 12 35-day-old lambs and 16 45-day-old lambs (11 Limousin lambs and 17 Romanovx Limousin lambs equally distributed between the 2 diets) were slaughtered. The carcasses were chilled for 24 hours and separated into 2 halves, the left one being dissected into muscles, bones and adipose tissues in a climatized room $\left( \pm 4^{\circ} \mathrm{C}\right)$. The different tissues were then ground in the frozen state using a "Stephan" screw-homogenizer filled with liquid nitrogen. About $700 \mathrm{~g}$ of the powder obtained was further homogenized with a "Robotcoupe" knife-grinder, and $120 \mathrm{~g}$ aliquots were kept at $-20^{\circ} \mathrm{C}$. 


\section{Chemical and mathematical analysis}

The aliquots of homogenized tissues, as well as, the milk and refusals were freezedried, and the dry weight controlled after equilibration in air-tight dessicators under vacuum. An additional correction for dry matter content was obtained after heat drying the powders for 48 hours at $80^{\circ} \mathrm{C}$ for all the samples, while dry matter content for the carcass tissues was further corrected for the water loss during chilling and dissection. The energy content of the different samples was determined with the help of a Gallenkamp adiabatic bomb calorimeter, their nitrogen content was determined according to the Kjeldahl method and ashes, after incinerating the dry samples for 8 hours at $550^{\circ} \mathrm{C}$. Protein content was calculated as $\mathrm{N} \times 6.25$ and non protein organic matter after the difference between dry matter and protein and ashes.

Statistical analysis of data involved the use of the non-parametric U-test of MannWhitney (Schwartz, 1969), 2-factor variance analysis and covariance analysis (Snedecor \& Cochran, 1971).

\section{RESULTS}

\section{Digestibility of the milk-substitutes}

A significant improvement in dry matter, energy and nitrogen digestibility occurred in the first replicate in 5-week-old lambs who were fed diet $\mathrm{Ta}$, but in the second one, digestibilities of diet $\mathrm{C}$ or diet Ta did not differ in 2-, 4-, or 6-week-old lambs (Table III). However, variance analysis showed that the effect of age on diet con- stituent digestibility was highly significant $(P<0.025)$ and explained respectively, $24 \%, 48 \%$ or $25 \%$ of the total variability in the case of dry matter, energy or nitrogen digestibilities. Variance analysis also showed a significant effect of the type of diet on $\mathrm{N}$ digestibility $(P<0.05)$, and a significant effect of replicate on energy digestibility $(P<0.005)$.

\section{Level of intake, growth and food effi- ciency}

In both replicates of part 1 of the trial, growth-rates were similar in lambs fed diet $\mathrm{C}$ or $\mathrm{Ta}$, as were levels of protein intake (Table IV), but energy intakes were $12.7 \%$ or $9 \%$ lower in lambs fed diet $\mathrm{Ta}$ $(P<0.05)$. Gross energy efficiency was significantly higher $(P<0.05)$ in lambs fed diet $\mathrm{Ta}(+18.9 \%$ or $+23.0 \%)$ respectively, in the first replicate or in the second one), but protein efficiency $(+4.4 \%$ or $+6.7 \%)$ was not significantly altered in lambs fed diet $\mathrm{Ta}$. However, when both replicates were considered together, the mean $5.3 \%$ higher protein efficiency observed in lambs fed diet Ta was significant $(P<0.05)$.

In the first replicate of part 2 of the trial, growth-rate was slightly lower in lambs fed diet $\mathrm{Ta}$, gross energy $(-16 \%)$ and protein $(-4 \%)$ intakes were also lower. Mean gross energy efficiency was $14 \%$ higher in lambs fed diet Ta, but no statistical analysis could be performed since the lambs were fed in groups; protein efficiencies were similar in lambs fed both types of diet. Compared to the data obtained in lambs fed diet $\mathrm{Ta}$, growth-rates $(-22 \%)$, gross energy $(-26 \%)$, and protein intakes $(-32 \%)$ were much lower in the lambs fed the experimental diet in restricted amounts (diet $T$ ). In this group of lambs, gross energy efficiency and protein efficiencies were $14 \%$ higher than in lambs fed diet C. 


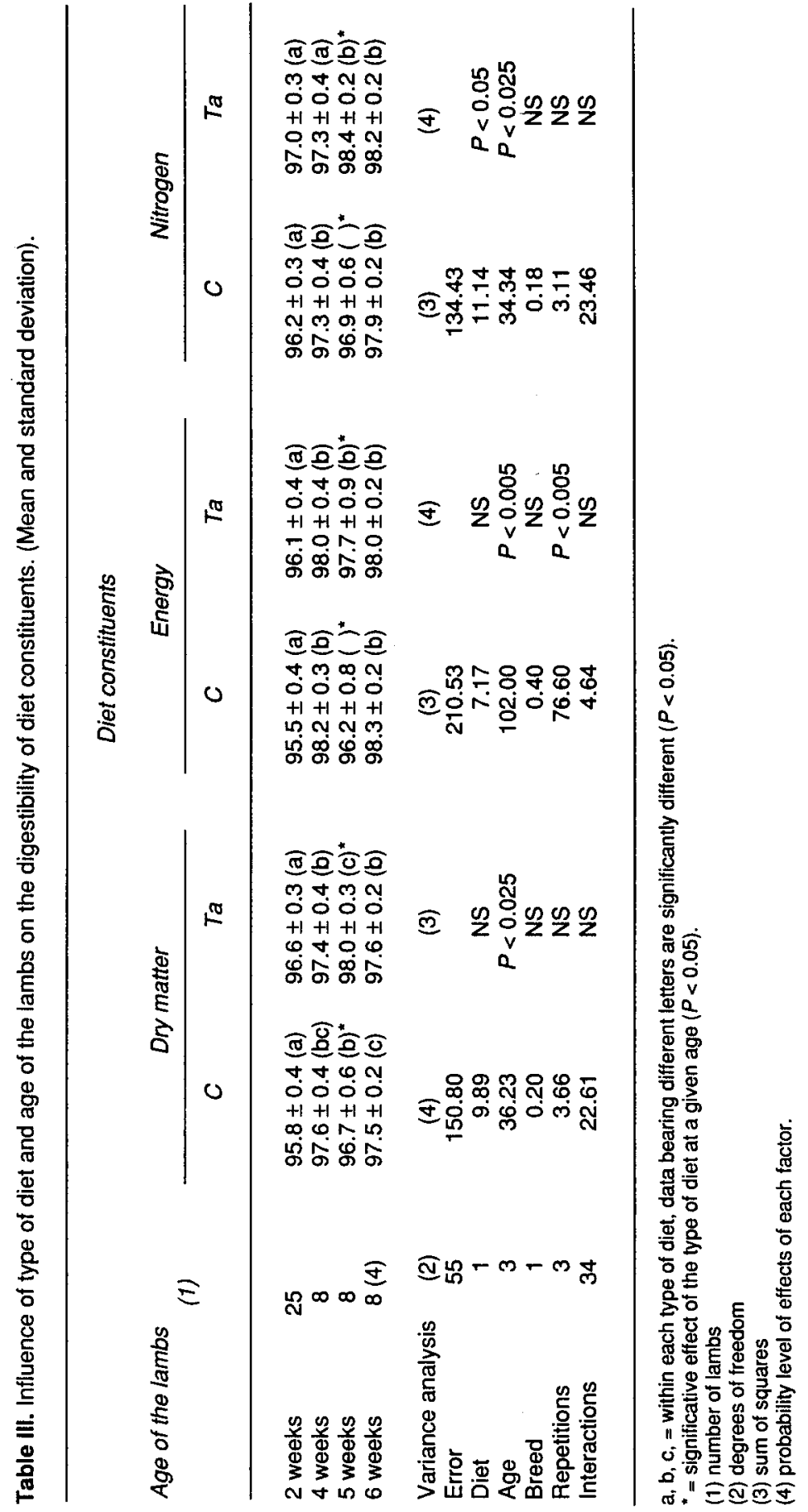


B. Aurousseau et al.

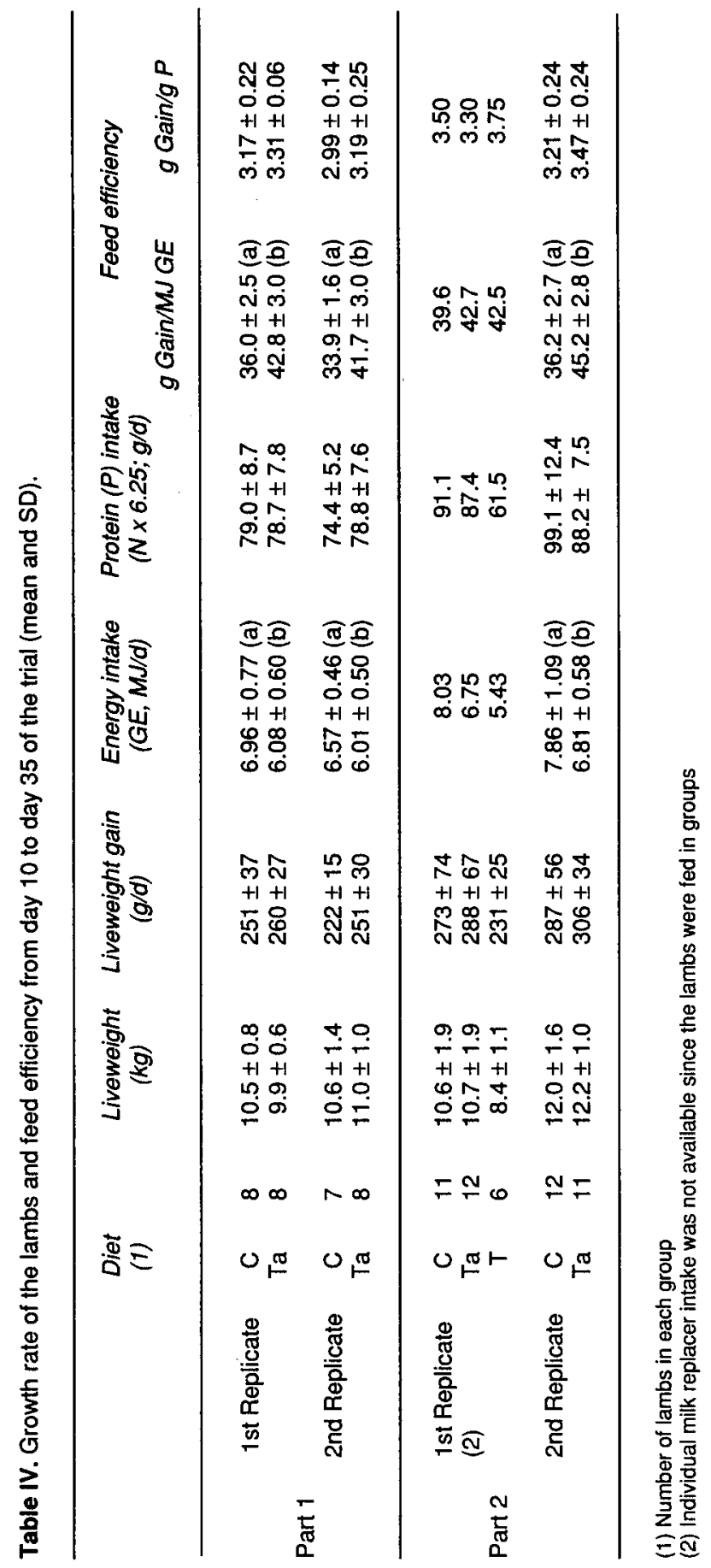


In the second replicate of part 2 of the trial, compared to the data obtained in lambs fed diet $C$, growth-rate was slightly higher $(+6.6 \%, \mathrm{NS})$; in lambs fed diet $\mathrm{Ta}$, gross energy intake was $13.4 \%$ lower $(P<0.05)$, and protein intake was similar. Thus, gross energy efficiency $(+24.9 \%)$ and protein efficiency $(+8.1 \%)$ were significantly $(P<0.05)$ higher in lambs fed diet $\mathrm{Ta}$, despite the lower energy intake.

\section{Nitrogen balance}

Since the levels of ME intake differed widely between lambs fed diets $\mathrm{C}$ or Ta (Tables $V$ and VI), nitrogen balance data had to be adjusted for similar ME intakes before being compared. Covariance analysis of the data, restricted to the 4 lambs per series which were used at all ages, showed a significant effect of the type of diet $(P<$ 0.005 ), on the slopes of the relationships between nitrogen balance (NF, $\mathrm{g} \mathrm{kg}^{-1}$ $\left.\left(W^{0.75}\right) d^{-1}\right)$, metabolizable energy intake (ME, MJ kg $\left.{ }^{-1}\left(W^{0.75}\right) \mathrm{d}^{-1}\right)$ and age of the lambs ( $A$, days), while the series of balance determinations had a significant effect on the constant. We obtained the following relationship in the case of $\operatorname{diet} \mathrm{C}$ :

$$
\begin{aligned}
& \mathrm{NF}=1.51 \mathrm{ME}-0.0178 \mathrm{ME} . \mathrm{A}-\text { constant } \\
& \text { (SD 0.13) (SD 0.0032) }
\end{aligned}
$$

(residual standard deviation $=0.144$;

$\left.r^{2}=0.971\right)$

or in the case of diet Ta :

$N F=2.08 \mathrm{ME}-0.0056 \mathrm{ME} . \mathrm{A}$ - constant (SD 0.21) (SD 0.0040)

(residual standard deviation $=0.173$;

$\left.r^{2}=0.883\right)$
In the first replicate, nitrogen balances, adjusted for similar ME intakes except for a $12 \%$ higher protein intake, were, in series 1 and $2,25.8$ and $18.1 \%$ or 19.4 and $34.9 \%$ higher, respectively, in 2- or 5 week-old lambs fed diet $\mathrm{Ta}$, compared to lambs of the same age fed diet $C(P<$ 0.005 ). Nitrogen balances in series 3 and 4 were 20.9 and $18.1 \%, 13.9$ and $15.3 \%$, or 20.0 and $20.5 \%$ higher in lambs fed diet $\mathrm{Ta}$ $(P<0.005)$, respectively in $2-, 4$ - or 6 week-old lambs.

Analysis of the carcasses of lambs slaughtered at weaning confirmed those results. The carcasses of lambs fed diet $\mathrm{Ta}$ had a $4.1 \%$ higher protein content, and the analysis of 14 carcasses of newborn Limousin lambs and of 9 carcasses of Romanov $\times$ Limousin lambs (Villette \& Aurousseau, 1981), allowed us to calculate a $12.5 \%$ higher nitrogen deposition between birth and slaughter in these lambs.

\section{Energy balance}

Protein deposition (Fig. 1) accounted for about $41.2 \%$ against 48.6 to $52.3 \%$ in 2week-old lambs from series 1 and 2, or for 27.3 to $31.9 \%$ against 37.3 to $43.1 \%$ of total energy deposited in 4- 5- or 6-week-old lambs, respectively, in lambs fed diet $C$ or in lambs fed diet Ta (Tables $\mathrm{V}$ and $\mathrm{VI}$ ). However, despite this effect on protein retention, efficiency of utilisation of metabolizable energy for energy deposition was not altered (Fig. 2). A single equation, therefore, related energy gain (EF, MJ/kg $\mathrm{W}^{0.75} / \mathrm{d}$ ) to ME intake (MJ/kg W0.75/d) :

$$
\begin{array}{ccc}
E F= & 0.72 \mathrm{ME} & -0.296 \\
(\text { SD 0.02) } & (\text { SD 0.008) }
\end{array} \quad \pm \begin{gathered}
0.015 \\
\left(r^{2}=0.982\right)
\end{gathered}
$$




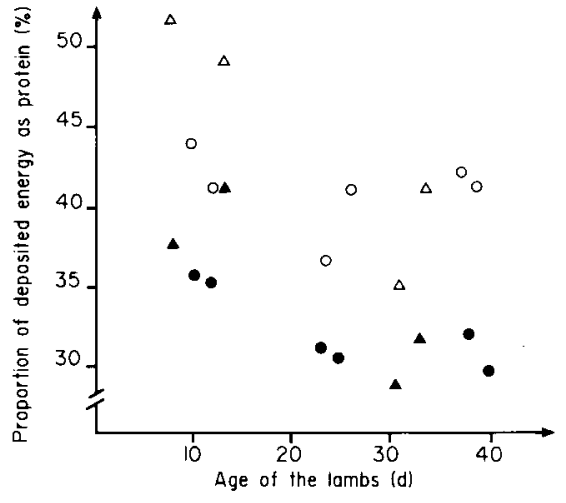

Fig. 1. Proportion of protein (p.100) in deposited energy according to the age and type of milk fed to the preruminant lamb (cosed symbols : lambs fed control tallow-coconut oil milk, C2; open symbols : lambs fed experimental tallow-coconut oiltricaprylin milk, T2; $\Delta \Delta$ : first replicate of trial 2; $\bullet$ : second replicate of trial 2).

The costs of protein (PF, MJ/kg W0.75/d) and lipid deposition (LF, MJ/kg W0.75/d) could be worked out according to the following relationship :

$$
\begin{aligned}
& M E=1.62 P F+1.15 \mathrm{LF}+0.451 \\
& (\mathrm{SD} 0.13) \quad(\mathrm{SD} 0.16)(\mathrm{SD} 0.044) \\
& \text { (residual standard deviation = } 0.056 ; \\
& \left.r^{2}=0.931\right)
\end{aligned}
$$

It showed an efficiency of $62 \%$ for protein deposition and $87 \%$ for lipid deposition. Maintenance energy requirements (MEm) amounted to $411 \pm 22 \mathrm{KJ} / \mathrm{kg}$ W $0.75 / \mathrm{d}$, according to the first relationship,

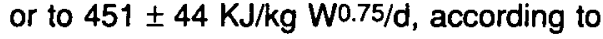
the second one.

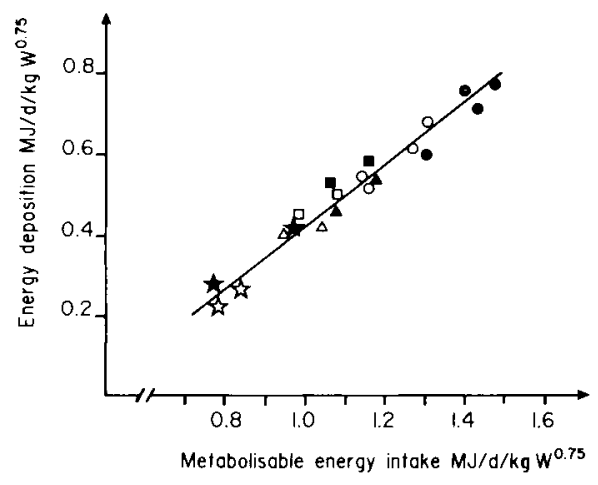

Fig. 2. Relationship between metabolizable energy intake and energy deposition (๑): 2-week-old lambs; $\mathbf{\theta}:$ : 4-week-ols lambs; $\Delta \Delta:$ 5-week-old lambs; $\star$ i : 6-week-old lambs. Closed symbols : lambs fed control tallow-coconut oil milk, C2; open symbols : lambs fed experimental tallowcoconut oil-tricaprylin milk, T2).

\section{DISCUSSION}

\section{Digestibility of the milk replacers}

The above reported results did not show any marked effect of tricaprylin on the digestibility of milk constituents. However, control diet $(C)$ afforded 5.3 of the dry matter or $9.1 \%$ of the energy as medium chain fatty acids (lauric and myristic acids) from coconut oil. Moreover, since part of the tricaprylin and of the lipids from diet $T$ floated, diet $\mathrm{Ta}$ finally provided only $7.6 \%$ of the energy as tricaprylin, accompanied by a loss of $3.5 \%$ of the energy as lauric 
Table V. First replicate of trial 2. Energy and protein fixation in the tissues of 2- or 5-week-old preruminant lambs fed a tallow-coconut oil diet (C) or a tallow-coconut oil-tricaprylin diet (Ta). (Mean and standard deviation.)

\begin{tabular}{|c|c|c|c|c|c|c|c|c|}
\hline \multirow{4}{*}{$\begin{array}{l}\text { Age of the lambs (weeks) } \\
\text { Diet } \\
\text { Series } \\
\text { Number of lambs }\end{array}$} & \multicolumn{4}{|c|}{2} & \multicolumn{4}{|c|}{5} \\
\hline & \multicolumn{2}{|c|}{ C } & \multicolumn{2}{|c|}{$T a$} & \multicolumn{2}{|c|}{$c$} & \multicolumn{2}{|c|}{$T a$} \\
\hline & 1 & 2 & 1 & 2 & 1 & 2 & 1 & 2 \\
\hline & 6 & 7 & 6 & 7 & 4 & 4 & 4 & $\overrightarrow{4}$ \\
\hline Age (d) & $\begin{array}{l}13.5 \\
(1.2)\end{array}$ & $\begin{array}{c}9.7 \\
(1.4)\end{array}$ & $\begin{array}{l}13.5 \\
(1.2)\end{array}$ & $\begin{array}{c}9.9 \\
(1.9)\end{array}$ & $\begin{array}{l}33.2 \\
(1.5)\end{array}$ & $\begin{array}{l}31.2 \\
(1.4)\end{array}$ & $\begin{array}{l}33.3 \\
(1.5)\end{array}$ & $\begin{array}{l}30.3 \\
(1.5)\end{array}$ \\
\hline Liveweight (kg) & $\begin{array}{c}6.5 \\
(0.9)\end{array}$ & $\begin{array}{c}6.4 \\
(0.9)\end{array}$ & $\begin{array}{c}6.8 \\
(1.0)\end{array}$ & $\begin{array}{c}6.1 \\
(0.8)\end{array}$ & $\begin{array}{l}12.8 \\
(1.1)\end{array}$ & $\begin{array}{l}12.7 \\
(0.8)\end{array}$ & $\begin{array}{l}12.3 \\
(0.7)\end{array}$ & $\begin{array}{l}12.2 \\
(0.8)\end{array}$ \\
\hline ME intake (MJ/d) & $\begin{array}{c}5.35 \\
(1.10)\end{array}$ & $\begin{array}{c}5.75 \\
(0.76)\end{array}$ & $\begin{array}{c}5.33 \\
(0.37)\end{array}$ & $\begin{array}{c}4.43 \\
(0.61)\end{array}$ & $\begin{array}{c}7.26 \\
(1.35)\end{array}$ & $\begin{array}{c}7.90 \\
(0.49)\end{array}$ & $\begin{array}{c}6.22 \\
(0.98)\end{array}$ & $\begin{array}{l}6.33 \\
(0.89)\end{array}$ \\
\hline Energy deposition (MJ/d) (1) & 2.41 & 2.83 & 2.59 & 1.91 & 3.61 & 3.95 & 2.70 & 2.81 \\
\hline Protein deposition (MJ/d) & $\begin{array}{c}0.99 \\
(0.21)\end{array}$ & $\begin{array}{c}1.17 \\
(0.18)\end{array}$ & $\begin{array}{c}1.26 \\
(0.05)\end{array}$ & $\begin{array}{c}1.00 \\
(0.18)\end{array}$ & $\begin{array}{c}1.12 \\
(0.29)\end{array}$ & $\begin{array}{c}1.08 \\
(0.13)\end{array}$ & $\begin{array}{c}1.11 \\
(0.41)\end{array}$ & $\begin{array}{c}0.98 \\
(0.32)\end{array}$ \\
\hline Lipid deposition (MJ/d) & 1.42 & 1.66 & 1.33 & 0.91 & 2.49 & 2.87 & 1.59 & 1.83 \\
\hline Nitrogen balance $(g / d)$ & $\begin{array}{c}6.672 \\
(1.387)\end{array}$ & $\begin{array}{c}7.841 \\
(1.162)\end{array}$ & $\begin{array}{c}8.428 \\
(0.313)\end{array}$ & $\begin{array}{c}6.695 \\
(1.191)\end{array}$ & $\begin{array}{c}7.514 \\
(1.320)\end{array}$ & $\begin{array}{c}6.624 \\
(0.961)\end{array}$ & $\begin{array}{c}7.443 \\
(2.701)\end{array}$ & $\begin{array}{c}6.597 \\
(2.145)\end{array}$ \\
\hline Adjusted $N$ balance $(g / d)(2)$ & 6.623 & 6.890 & 8.336 & 8.137 & 7.314 & 5.578 & 8.732 & 7.528 \\
\hline
\end{tabular}

(1) Energy balance was measured on groups of lambs on which individual nitrogen balance was obtained.

(2) Data adjusted, according to the relationships given in page 92 , for a liveweight of $6.3 \mathrm{~kg}$, a ME intake of $5.2 \mathrm{MJ} / \mathrm{d}$ (9.9 or $11.1 \mathrm{mg} \mathrm{Nd} / \mathrm{d}$ respectively, with $\mathrm{C} 2$ or T2 milk) and an age of 12 days in 2-weeks-old lambs; and for a liveweight of $12.5 \mathrm{~kg}$, a ME intake of $6.9 \mathrm{MJ} / \mathrm{j}(13.9$ or $15.4 \mathrm{mg} \mathrm{Nd} / \mathrm{d}$ respectively, with $\mathrm{C} 2$ or T2 milk) and an age of 32 days in 5-week-old lambs.

and myristic acids. The slight difference in the amounts of medium chain fatty acid between the two diets could explain the absence of effect of tricaprylin on the digestibility of the constituents of the experimental diet. Moreover, the lower content of fat of diet Ta may have decreased the rate of carbohydrate absorption by the intestine (Roy, 1969).

\section{Level of intake, growth and food effi- ciency}

A similar level of protein intake was obtained in lambs fed diets $\mathrm{C}$ or Ta, which, due to the different energy/protein ratio in the two diets, corresponded to a $14.7 \%$ lower energy intake in lambs fed diet Ta. 


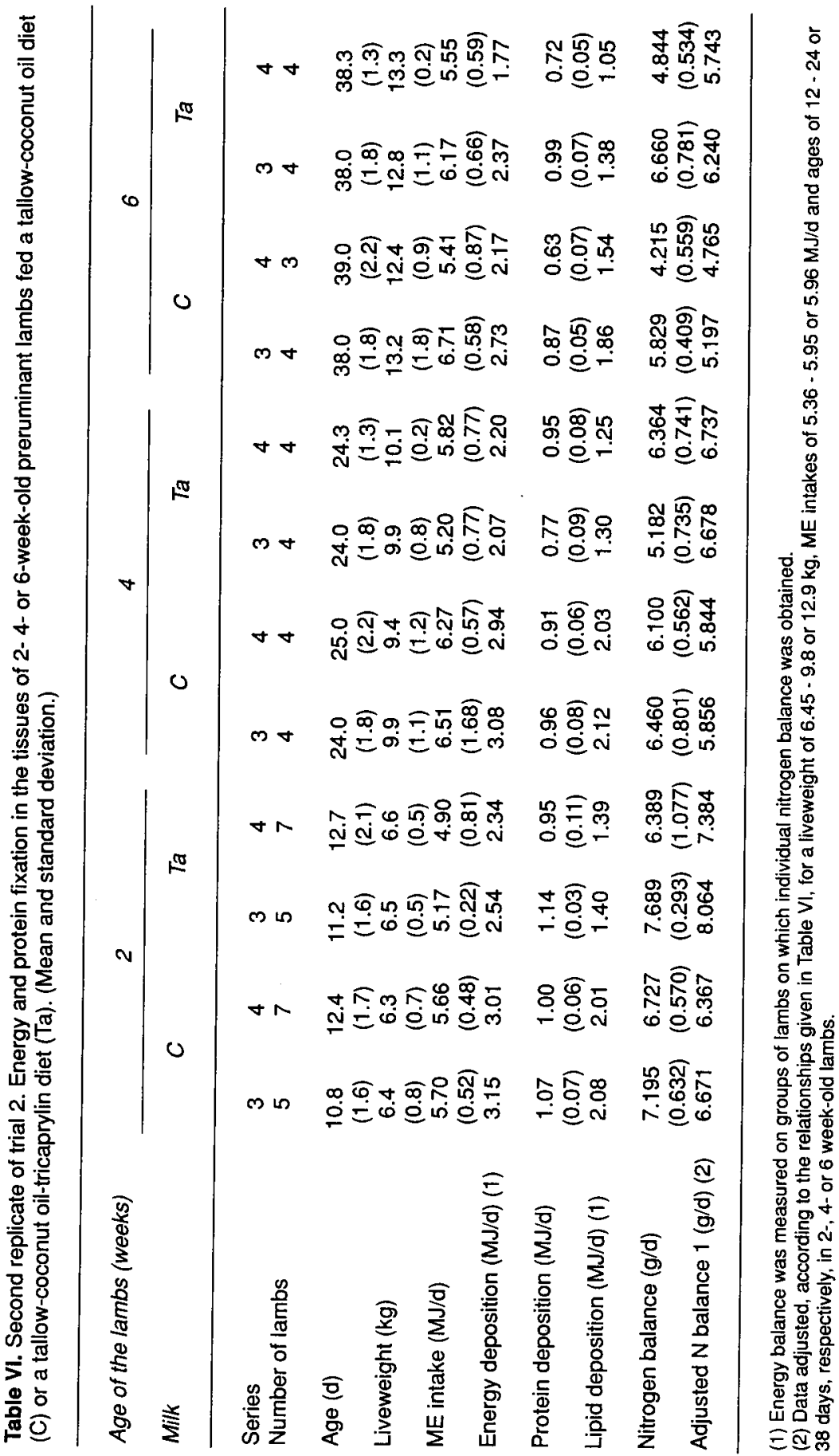


Both proteins and energy are needed for protein deposition and growth. Previous studies of the requirements of the preruminant lamb showed that the protein need was fulfilled when the milk replacer had a protein content of $25 \%$ of DM. Thus, Chiou and Jordan (1973) observed a $17 \%$ decrease in protein efficiency when the protein content of the milk replacer was increased from $15 \%$ to $23 \% \mathrm{DM}$, and a further $11.8 \%$ decrease when it was increased from $23 \%$ to $30 \%$ DM (Dove, Pearce \& Tribe, 1977), also observed a $2.7 \%$ decrease in protein efficiency when the protein content of the diet was increased from 17.5 to $20.9 \% \mathrm{DM}$, and a further $11.8 \%$ decrease when it was increased from $20.9 \%$ to $25.9 \%$ DM. In a previous work (Aurousseau, 1984), we failed to observe any alteration in protein efficiency when the protein content of the milk replacer was increased from $25 \%$ to $30 \%$ DM. Therefore, the significant $5.3 \%$ to $8.1 \%$ increase in protein efficiency observed in lambs fed diet $\mathrm{Ta}$, did not appear to be bound to the different protein content of the two diets, but more likely to an effect of the different nature of their energy. However, the loss of part of the lipids from diet Ta led to the replacement of $14.1 \%$ of the energy of diet $C(10.6 \%$ as long chain fatty acids, and $3.5 \%$ as lauric and myristic acids) by $7.6 \%$ and $6.5 \%$ of the energy, respectively, as caprylic acid or as carbohydrates. It is therefore not possible to ascribe the observed effect to tricaprylin intake or to increased carbohydrate content of the milk.

\section{Nitrogen balance}

The overall effect of diet Ta on adjusted nitrogen balance was homogenous, varying between +13.9 and $+25.8 \%$, with a maxi- mum of $+34.9 \%$ in 5-week-old lambs from series 2. These effects were, however, higher than the effect obtained according to carcass analysis (about $+12.5 \%$ ). This discrepancy could be easily explained by the errors bound to the floatation of part of the fat from diet $\mathrm{Ta}$ and the difficulties encountered in analysis of the composition of the liquid diet refusals. It can also be explained by the fact that carcass analysis gave crude results corresponding to a much lower level of energy intake in lambs fed diet Ta. Another hypothesis would be a higher effect of diet Ta on nitrogen deposition in non-carcass tissues, since we previously observed a significant increase in the development of gastrointestinal organs when the protein content of the diet offered to preruminant lambs was increased (Aurousseau, 1984).

As previously observed for tricaproin in the calf (Aurousseau et al., 1983), the tricaprylin effect seemed to occur in the addition of coconut oil. However, as discussed above, in the case of feed efficiency diet Ta differed from diet $C$ in three main ways: a) a $14 \%$ higher protein content, b) a $4.1 \%$ higher medium chain fatty acid content (although tricaprylin content amounted to $7.6 \%$ of the energy of the diet, lauric and myristic acids content being taken down from 9.1 to $5.6 \%$ ), and c) a $6.5 \%$ higher content of energy from carbohydrates.

According to a previous study (Aurousseau, 1988), the effect of the increased protein content of diet Ta could explain only $2.4 \%, 1.6 \%, 1.1 \%$ or $0.4 \%$ of the differences of nitrogen balances observed with each type of diet, respectively, in 2-, 4-, 5- or 6-week-old lambs.

Caprylic acid intake per se could lead to an increase in nitrogen balance and growth as observed in the calf (Aurousseau, Vermorel \& Bouvier, 1984; Aurousseau, Thivend \& Vermorel, 1984) or in the lamb (Aurousseau et al., 1989), but the ex- 
tent of those effects were much more limited than those reported in this trial : furthermore, they were restricted to the younger animals.

Part of the increased protein deposition in lambs fed diet Ta could also be explained by the higher carbohydrate content of the milk. On the one hand, addition of soluble carbohydrates (Mathieu \& De Tugny, 1965; Lodge \& Lister, 1973) have been shown to improve nitrogen balance in the young 2- to 4-week-old calf, but addition of high amounts of carbohydrates were required to achieve similar levels of effects to those obtained in the above study, and glucose effects were limited by the occurrence of health disorders when the glucose content of the diet was too high. On the other hand, the incorporation of $15 \%$ starch in the milk replacer offered to the preruminant calf can lead to a $14 \%$ increase of nitrogen balance, but this effect was not obtained in young calves of under $100 \mathrm{~kg}$ liveweight, and in older calves, did not reach the high level observed in 6-week-old lambs fed diet $\mathrm{Ta}$ (Vermorel et al., 1974).

However, caprylic acid was also shown to increase the rate of glucose uptake in the organism of the young rat (Pegorier et al., 1983), and, when enough glucose is available, to favour an increased rate of insulin production from the pancreas (Borg, 1981; Campillo et al., 1982). An increase of plasma insulin can also stimulate thyroid hormone production in the young lamb (Koppel et al., 1982) and favour an increased production of high energy bonds for protein synthesis. All those features of control of the metabolism of growing animals, as well as, the higher effect than previously observed of either tricaprylin or carbohydrates on nitrogen balance in the experimental lambs, both at 2 or at 6 weeks, are in favour of a synergistic effect of tricaprylin and carbohydrates in diet $\mathrm{Ta}$, which could possibly be obtained as well with supplements of coconut oil and carbohydrates.

\section{Energy balance}

As previously observed in young veal calves (Aurousseau, Vermorel \& Bouvier, $1983,1984)$, despite the significant effects of the type of dietary fat on efficiency of protein deposition, no significant effect on efficiency of metabolisable energy utilisation for energy deposition was obtained. This fact is easily explained if one considers the extent of the effect on protein deposition $(+13$ to $+25 \%)$ and the respective efficiencies of energy utilisation for protein and lipid deposition previously obtained, i.e. 43 to $53 \%$ and 95 to $100 \%$ (Kirchgessner et al., 1976; Aurousseau, Vermorel \& Bouvier, 1983, 1984, in the preruminant calf; Aurousseau, 1988, in the preruminant lamb). It appears that energy deposition should be altered by 6 to $8 \%$, which, due to the determination of energy balances on groups of lambs of widely different potentialities for growth, cannot be pointed out. The higher efficiency of metabolisable energy for protein deposition $(62 \%)$, than previously reported ( 43 to $53 \%$ ), may be related to the use of two diets, $\mathrm{C}$ and $\mathrm{Ta}$, which both favour efficiency of utilisation of digestible nitrogen for retention in the tissues, while the lower efficiency for fat deposition $(87 \%)$, than previously reported (95 to $100 \%$ ), may be related to a stimulation of lipid synthesis from carbohydrates. 


\section{CONCLUSIONS}

In the present study, no effect of tricaprylin intake on the digestibility of the constituents of the milk-substitutes was observed, very likely due to the small amount of tricaprylin ingested by the lambs. The effects of tricaprylin on nitrogen balance have been biased by the flotation of part of the lipids of the corresponding diet, so that the effects obtained could not be clearly assigned to one of the two major factors of difference between diets $\mathrm{C}$ and $\mathrm{Ta}$ : the addition of tricaprylin $(7.6 \%$ of the energy) and the higher carbohydrate content $16.5 \%$ of the energy) in diet Ta. Tricaprylin intake per se seemed of major importance in the effects obtained in 2-week-old lambs, while the increase in carbohydrate content of the diet per se seemed of major importance in 6-week-old lambs; however, an interaction between both tricaprylin intake and increased carbohydrate content of the diet is necessary to explain the level of the effect obtained as well in 2-week-old lambs, or when the lambs grew older. Growth of the lambs fed diet Ta has been favoured, but further studies are needed to study the mechanism by which nitrogen balance was increased and the respective effects of tricaprylin or increased carbohydrate content of the diet. The above reported results show a more clear-cut effect in the alteration of the source of energy of the diet on nitrogen balance and growth of the young lamb than ever previously obtained and are of great interest for the preparation of milks fitted to improve the nutrition of the low birth-weight lambs.

\section{REFERENCES}

Aurousseau B. (1984) Effets combinés de l'apport d'acide caproîque et de la concentration en protéines sur l'utilisation de laits artificiels par l'agneau préruminant. II. Croissance et composition corporelle des agneaux. Ann. Zootech. 33, 201-218

Aurousseau B. (1988) Effects of substitution of tricaproin for tallow and of protein concentration in milk substitutes on nitrogen and energy balance in the preruminant lamb. Br. J. Nutr. 60 , 525-538

Aurousseau B. Theriez M. \& Daniel M. (1973) Influence de la nature des matières grasses incorporées dans l'aliment d'allaitement sur le métabolisme lipidique de l'agneau de boucherie. Ann. Biol. Anim. Bioch. Biophys. 13, 93-105

Aurousseau B., Vermorel M. \& Bouvier J.C. (1983) Influence du remplacement d'une partie du suif d'un aliment d'allaitement par de la tricaproine ou de l'huile de coprah sur l'utilisation de "énergie et de l'azote par le veau préruminant. Influence du niveau d'alimentation antérieur. $R e$ prod. Nutr. Dev. 23, 587-597

Aurousseau B., Thivend P. \& Vermorel M. (1984) Influence du remplacement d'une partie du suif ou de la tricaproine en association à de l'huile de coprah sur la croissance du jeune veau préruminant. Ann. Zootech. 33, 219-234

Aurousseau B., Vermorel M. \& Bouvier J.C. (1984) Influence du remplacement d'une partie du suif d'un aliment d'allaitement par la tricapryline ou de l'huille de coprah sur l'utilisation de l'énergie et de l'azote par le veau préruminant. Reprod. Nutr. Dev. 24, 265-279

Aurousseau B., Vermorel M., Theriez M. \& Vezinhet A. (1989) Effects of substitution of tricaprylin or coconut oil for tallow in milk replacers offered to preruminant lambs. Ann. Zootech. 38

Baba N., Bracco F. \& Hashim S.A. (1982) Enhanced thermogenesis and diminished deposition of fat in response to overfeeding with diet 
containing medium chain triglyceride. $A m$. $J$. Clin. Nutr. 35, 678-682

Borg L.A.H. (1981) Effects of octanoate and ketone bodies on the structure and function of isolated pancreatic islets in tissue culture. Acta Endocrinol. 96, 508-518

Brisson G.J., Bouchard R. \& Morisset-Rochette M. (1970) Equipment for nutritional studies with lambs weaned at 3 days of age and reared on experimental diets. J. Anim. Sci. 31, 417-421

Campillo J.E., Luickx A.S. \& Lefebvre P.J. (1982) Effect of oleic and octanoic acid on glucose and insulin secretion in vitro. Horm. Metab. Res. 14, 499

Chiou P.W.S. \& Jordan R.M. (1973) Ewe milk replacer diets for young lambs. III. Effect of age of lambs and dietary protein and fat levels on the body composition of young lambs. J. Anim. Sci. 36, 607-612

Dove H., Pearce G.R. \& Tribe D.E. (1977) Utilization of amino acids by preruminant lambs. II. The effects of independent alterations in total nitrogen and total essential amino acid intake. Aust. J. Agric. Res. 28, 933-946

Huston R.K., Reynolds J.W., Jensen C. \& Buist N.R.M. (1983) Nutrient and mineral retention and vitamin $D$ absorption in low birth-weight infants : effects of medium chain triglycerides. $\mathrm{Pe}$ diatrics $72,44-48$

Kirchgessner M., Muller M.L. \& Neesse K.R. (1976) Energy retention and utilization by the veal calf. In : Energy Metabolism of Farm Animals. EAAP No. 19, (M. Vermorel G. de Bussac, ed). Clermont-Ferrand, pp. 201-204

Koppel J., Kuchar S., Mozes S., Herzova J. \& Boda D. (1982) Effect of subcutaneous and intraperitoneal administration of insulin on the milk intake of suckling lambs. Horm. Metabol. Res. 12, 631-633

Lodge G.A. \& Lister E.E. (1973) Effects of increasing the energy value of a whole milk diet for calves. I. Nutrient digestibility and nitrogen retention. Can. J. Anim. Sci. 63, 307-316

Mathieu C.M. \& De Tugny H. (1965) Digestion et utilisation des aliments par le veau préruminant à l'engrais. III. Remplacement des matières grasses du lait par du glucose. Ann. Biol. Anim. Biochim. Biophys. 5, 21-39
Newport M.J., Storry J.E. \& Tuckley B. (1979) Artificial rearing of pigs. VII. Medium chain triglycerides as a dietary source of energy and their effect on live weight gain, feed : gain ratio, carcass composition and blood lipids. Br. J. Nutr. 41, 85-93

Pegorier J.P., Leturque A., Ferre P., Turlan P. \& Girard J. (1983) Effects of medium chain triglycerides feeding on glucose homeostasis in the newborn rat. Am. J. Physiol. 244, E329-E334

Roy (1969) Diarrhea of nutritional origin. Proc. Nutr. Soc. 28, 160-170

Schwartz D. (1969) Les tests non paramétriques : buts et principaux tests. In : Méthodes Statistiques à l'Usage des Médecins et Biologistes, 3rd ed. Flammarion Médecine Science, Paris, pp. 245-247

Snedecor G.W. \& Cochran W.G. (1957) Statistical Methods. 6th ed. Trad. H. Boelle \& E. Cammaji (1971) Association de Coordination Technique Agricole, Paris, pp. 524-559

Theriez M., Molenat G., Daniel M. \& Aurousseau B. (1973) L'allaitement artificiel des agneaux. III. Influence de la nature des matières grasses incorporées dans l'aliment d'allaitement. Ann. Zootech. 22, 185-197

Vermorel M., Bouvier J.C., Bonnet Y. \& Fauconneau G. (1973) Construction et fonctionnement de 2 chambres respiratoires de type "circuit ouvert" pour jeunes bovins. Ann. Biol. Anim. Bioch. Biophys. 13, 659-681

Vermorel M., Bouvier J.C., Thivend P. \& Toullec R. (1974) Utilisation énergétique des aliments d'allaitement par le veau préruminant à l'engrais à différents poids. In : Energy Metabolism of Farm Animals, EAAP No. 14. (K.H. Menke, H.J. Lantzxh \& J.R. Reichl, eds). Univerversitât Hohenheim Dokumentationstelle, Stuttgart, pp. 143-146

Villette Y. \& Aurousseau B. (1981) Influence du poids à la naissance et du génotype sur la composition chimique de l'agneau nouveau-né. Ann. Zootech. 30, 285-298

Walker D.M. \& Stokes G.B. (1970) The nutritive value of fat in the diet of the milk fed lamb. I. The apparent and corrected digestibilities of different fats and their constituent fatty acids. $B r$. J. Nutr. 24, 425-433 